JURNAL PENDIDIKAN AKUNTANSI DAN KEUANGAN

Vol. 7, No. 1, [Januari-Juni], 2019: 21-30

\title{
Pajak, Mekanisme Bonus dan Transfer Pricing
}

\author{
Radhi Abdul Halim Rachmat \\ Universitas Widyatama, Bandung, Indonesia
}

\begin{abstract}
The practice of transfer pricing is mostly carried out by multinational companies that want high profits through tax avoidance. in addition, bonus giving is also one of the motivations for obtaining high profits. This study aims to examine the effect of tax and bonus mechanisms on the company's decision to conduct transfer pricing. The research population used in this study were manufacturing companies listed on the IDX (Indonesia Stock Exchange) period 2013 - 2017 which amounted to 142 companies and research samples totaling 23 companies using purposive sampling method. The analysis technique used in this study used logistic regression analysis. The results of the research partially indicate that tax has a significant effect on transfer pricing and the bonus mechanism has a significant effect on transfer pricing. The impact of transfer pricing has the potential to harm state revenues in the taxation sector, because companies will divert their taxable profits to countries that have lower tax rates.
\end{abstract}

Keywords. tax; bonus mechanism; transfer pricing practices

\begin{abstract}
Abstrak
Praktik transfer pricing mayoritas dilakukan oleh perusahaan multinasional yang menginginkan laba tinggi melalui penghindaran pajak. selain itu, pemberian bonus juga merupakan salah satu motivasi untuk mendapatkan laba yang tinggi. Penelitian ini bertujuan untuk meneliti pengaruh pajak dan mekanisme bonus terhadap keputusan perusahaan untuk melakukan transfer pricing. Populasi penelitian yang digunakan dalam penelitian ini adalah perusahaan manufaktur yang terdaftar di BEI (Bursa Efek Indonesia) periode 2013 - 2017 yang berjumlah 142 perusahaan dan sampel penelitiam yang berjumlah 23 perusahaan dengan menggunakan metode purposive sampling. Teknik analisis yang digunakan pada penelitian ini menggunakan analisis regresi logistik. Hasil dari penelitian secara parsial menunjukkan bahwa pajak berpengaruh signifikan terhadap transfer pricing dan mekanisme bonus berpengaruh signifikan terhadap transfer pricing. Dampak transfer pricing berpotensi merugikan pendapatan negara pada sektor perpajakan, dikarenakan perusahaan akan mengalihkan laba kena pajaknya pada negara yang memiliki tarif pajak yang lebih rendah
\end{abstract}

Kata Kunci. pajak; mekanisme bonus; praktik transfer pricing

Corresponding author. Email. radhi.abdul@widyatama.ac.id

How to cite this article : Abdul, R., \& Rachmat, H. (2019). Pajak, Mekanisme Bonus dan Transfer Pricing. Jurnal Pendidikan Akuntansi Dan Keuangan, 7(1), 21-30. Retrieved from http://ejournal.upi.edu/index.php/JPAK/article/view/15801

History of article. Received: Agustus 2018, Revision: Oktober 2018, Published: Januari 2019

\section{PENDAHULUAN}

Transfer pricing menjadi sebuah isu sangat yang menarik untuk di teliti di dalam bidang perpajakan seiring semakin bekembangannya perusahaan multinasional. menurut Suandy (2011: 74), banyak studi yang menunjukan lebih dari $80 \%$ perusahaan-perusahaan multinasional (MNC) melihat transfer pricing sebagai suatu isu perpajakan internasional utama, dan lebih dari setengah perusahaan mengatakan bahwa isu ini merupakan isu yang penting. transfer pricing dapat mengakibatkan berkurangnya potensi penerimaan negara dari sektor pajak suatu negara karena perusahaan cenderung menggeser kewajiban perpajakannya dari negara yang memiliki tarif pajak yang tinggi (high tax countries) ke negara yang menerapkan tarif pajak rendah (low tax countries). Direktur Jenderal Pajak, Ken Dwijugiasteadi, mengungkapkan bahwa terdapat 2000 perusahaan multinasional yang beroperasi di Infonesia tidak membayar pajak penghasilan badan 10 tahun terakhir karena alasan merugi. Menurut perhitungan Ditjen 
Pajak, negara berpotensi kehilangan 1.300 Triliun Rupiah akibat dari praktik transfer pricing. Bahkan lebih dipertegas lagi menurut informasi internal Ditjen Pajak bahwa kehilangan tersebut kebanyakan akibat adanya pembayaran Bunga, Royalti serta Intragroup Service, sehingga Ditjen Pajak percaya bahwa dengan menyetop pembayaran tersebut negara sudah tidak perlu menambah hutang lagi (Haeruman, 2014). Kegiatan usaha melalui transfer pricing dapat menghindari pajak berganda (Price water house Coopers, 2009, dalam Hartati et al., 2014). Transfer pricing sering mengalami masalah dalam aspek penyalahgunaan pajak, karena transfer pricing menyangkut masalah bea cukai, ketentuan anti-dumping, perubahan pengalihan penghasilan, dan perubahan dasar pengenaan pajak (tax base) dari satu wajib pajak kepada wajib pajak lain. Dengan kata lain, realitanya adalah transfer pricing dapat menimbulkan kemungkinan rekayasa jumlah pajak yang terutang atas perusahaan yang mempunyai hubungan istimewa tersebut (Hartati et al., 2014).

Selain didasarkan pada penghidaran beban pajak yang lebih besar, praktik transfer pricing pun dapat dipengaruhi oleh alasan non pajak seperti mekanisme bonus. Bonus adalah bentuk penghargaan yang diberikan oleh pemilik perusahaan melalui Rapat Umum Pemegang Saham (RUPS) kepada manajemen terutama anggota direksi setiap tahun apabila kinerja dinilai baik. Penilaian kinerja perusahaan dapat dinilai berdasarkan perolehan laba. Hal tersebut yang memotivasi manajemen untuk merekayasa atau mengatur laba bersih dengan maksud mendapatkan bonus yang akan mereka terima (Purwanti, 2010). Transfer pricing adalah salah satu cara yang dapat dilakukan untuk mencapai tujuan tersebut.

Berdasarkan latar belakang yang telah diuraikan, maka penelitian akan menguji "Pajak, Mekanisme Bonus dan Praktik
Transfer Pricing : Empirikal study". Penelitian ini menggunakan perusahaan manufaktur yang terdaftar di Bursa Efek Indonesia tahun 2011-2015 sebagai sampel. Karena perusahaan manufaktur di indonesia banyak yang merupakan perusahaan yang memiliki hubungan istimewa dengan perusahaan yang ada diluar negeri.

\section{KAJIAN PUSTAKA}

\section{Transfer Pricing}

Pengertian transfer pricing dapat dibedakan menjadi dua, yaitu pengertian yang bersifat netral dan pengertian yang bersifat pejorative. Pengertian netral mengasumsikan bahwa transfer pricing adalah strategi dan taktik bisnis tanpa motif pengurangan beban pajak. Sedangkan pengertian pejorative mengasumsikan transfer pricing sebagai upaya untuk menghemat beban pajak dengan cara menggeser laba ke negara yang mempunyai tarif pajak yang rendah (Suandy, 2011). Transfer pricing adalah kebijakan suatu perusahaan dalam menentukan harga transfer suatu transaksi.Transfer pricing adalah kebijakan suatu perusahaan dalam menentukan harga transfer suatu transaksi. Transfer pricing dapat terjadi dalam satu perusahaan (intracompany) dan antar perusahaan (intercompany) yang terikat dalam hubungan istimewa (Ikatan Akuntan Indonesia, 2013). Transfer pricing sering juga disebut dengan intracompany pricing, intercorporate pricing, interdivisional atau internal pricing yang merupakan harga yang diperhitungkan untuk keperluan pengendalian manajemen atas transfer barang dan jasa antar anggota (grup perusahaan) (Hadi Muttaqin, 2012). Menurut Plasschaet (1998), definisi transfer pricing adalah suatu rekayasa manipulasi harga secara sistematis dengan maksud mengurangi laba, membuat seolah-olah perusahaan rugi, menghindari pajak atau bea di suatu negara. Plasschaert memberikan definisi transfer pricing sebagai suatu rekayasa harga yang membuat seolah perusahaan rugi sehingga 
mengurangi pajak yang seharusnya dikenakan di suatu negara. Rekayasa tersebut bisa memanfaatkan tarif pajak di suatu negara dengan menggeser laba tersebut ke tarif pajak yang paling rendah (Gunadi, 1994: 9; Yuniasih dkk, 2011). Transfer pricing biasanya ditetapkan untuk produk-produk antara (intermediate product) yang merupakan barang-barang dan jasa-jasa yang dipasok oleh divisi penjual kepada divisi pembeli. Pasal 1 ayat (8) Peraturan Direktur Jenderal Pajak Nomor PER-43/PJ/2010 yang diubah terakhir dengan PER- 32/PJ/2011, mendefinisikan penentuan harga transfer (transfer pricing) sebagai penentuan harga dalam transaksi antara pihak-pihak yang mempunyai hubungan istimewa.

\section{$\operatorname{Tax}$}

Pajak adalah iuran rakyat kepada kas Negara berdasarkan Undang - Undang (yang dapat dipaksakan) dengan tidak mendapat jasa timbal (kontra Prestasi) yang langsung dapat ditunjukkan dan yang digunakan untuk membayar pengeluaran umum (Mardiasmo, 2011). pajak memiliki unsur-unsur yaitu iuran dari rakyat kepada negara, berdasar pada Undang-Undang, tanpa adanya kontraprestasi secara langsung dari Negara, dan dipergunakan untuk membiayai rumah tangga Negara. Salah satu cara untuk mengukur seberapa baik sebuah perusahaan mengelola pajaknya adalah dengan melihat tarif pajak efektifnya (Liansheng et al., 2007). PricewaterhouseCoopers (PWC) merumuskan effective tax rate (ETR) sebagai pajak penghasilan terutang dibagi dengan penghasilan sebelum pajak (Handayani, 2013).

\section{Mekanisme Bonus}

Mekanisme bonus adalah imbalan yang diberikan pemilik perusahaan kepada manajer karena memenuhi sasaran kinerja perusahaan, seorang manajer mungkin memperoleh bonus berdasarkan laba bersih, atau menurut target kenaikan laba bersih (Hansen dan Mowen,
2005). Lo et al (2010) menemukan bahwa manajer lebih menyukai untuk meningkatkan laporan laba dengan cara meningkatkan laba dari penjualan pihak terkait jika bonus didasarkan pada laporan laba perusahaan dengan menggunakan Index Trend Laba Bersih (ITRENDLB). Hartati et al (2014) dan Nurjanah et al (2016) bahwa direksi untuk mendapatkan bonus dari pemilik perusahaan akan berusaha untuk memaksimalkan peningkatan laba perusahaan secara keseluruhan dengan memanfaatkan transfer pricing. Pemberian bonus tidak hanya didasarkan pada perolehan besarnya laba pada setiap periode, melainkan juga pada kinerja direksi dalam mengelola perusahaan, sehingga pihak direksi cenderung akan menunjukkan kinerjanya terhadap pemilik perusahaan untuk memperoleh sebuah penghargan atau bonus.

\section{Pajak dan Keputusan Transfer Pricing}

Salah satu alasan perusahaan melakukan transfer pricing adalah pajak. Dengan meminimalisir beban pajak perusahaan melalui transfer pricing dapat meningkatkan keuntungan. Motivasi pajak dalam transfer pricing pada perusahaan multinasional dilaksanakan dengan cara memindahkan kewajiban perpajakannya ke negara dengan tarif pajak rendah, dimana perusahaan memiliki grup atau divisi yang beroperasi di negara tersebut. Perusahaan multinasional melakukan transfer pricing untuk meminimalkan beban pajak perusahaan secara global (Gusnardi, 2010). Penelitian tersebut sejalan dengan penelitian yang dilakukan oleh Yuniasih, Rasmini, dan Wirakusuma (2011) yang menunjukkan bahwa pajak berpengaruh positif terhadap transfer pricing. Berdasarkan uraian tersebut maka hipotesis pertama penelitian ini adalah :

\section{H1 : Pajak berpengaruh terhadap keputusan perusahaan melakukan praktik transfer pricing.}




\section{Mekanisme Bonus dan Transfer Pricing}

Salah satu cara direksi untuk mendapatkan bonus yaitu dengan memaksimalkan laba. Bonus merupakan kompensasi tambahan atau penghargaan yang diberikan kepada pegawai atas keberhasilan pencapaian tujuan-tujuan yang ditargetkan oleh perusahaan. Mekanisme bonus berdasarkan laba merupakan cara yang paling sering digunakan perusahaan dalam memberikan penghargaan kepada direksi atau manajer (Thesa Refgia, 2017). Skema bonus direksi juga dapat diartikan sebagai pemberian imbalan di luar gaji pokok kepada direksi perusahaan atas hasil kerja yang dilakukan dengan melihat kinerja direksi itu sendiri. Maka, karena berdasarkan tingkat laba direksi atau manajer dapat memanipulasi laba tersebut untuk memaksimalkan penerimaan bonus (Irpan, 2010). Lo et al (2010) menemukan bahwa manajer lebih menyukai untuk meningkatkan laporan laba dengan cara meningkatkan laba dari penjualan pihak terkait jika bonus didasarkan pada laporan laba perusahaan. Semakin tinggi laba perusahaan secara keseluruhan yang dicapai, maka semakin tinggi apresiasi yang diberikan oleh pemilik kepada direksi. Oleh sebab itu, praktik transfer pricing dipilih oleh direksi untuk memaksimalkan laba perusahaan. mungkin menaikan laba perusahaan secara keseluruhan dengan cara melakukan praktik transfer pricing. Merujuk pada penilitian yang dilakukan oleh Hartati dkk (2014) membuktikan bahwa pemilik perusahaan akan mempertimbangkan pencapaian laba perusahaan yang dicapai secara keseluruhan untuk melakukan penilaian atas prestasi kinerja direksinya sehingga para direksi akan berusaha semaksimal mungkin menaikkan laba perusahaan secara keseluruhan dengan cara melakukan praktik transfer pricing. Hipotesis yang dirumuskan adalah:

H2: Mekanisme bonus berpengaruh terhadap keputusan perusahaan melakukan praktik transfer pricing.

\section{METODE PENELITIAN}

Metode yang digunakan dalam penelitian ini adalah penelitian eksplanatori. Penelitian eksplanatori adalah penelitian yang bertujuan untuk menelaah kausalitas antarvariabel yang menjelaskan suatu fenomena tertentu dan menjelaskan hubungan antara variabelvariabel penelitian dan menguji hipotesis yang telah diajukan (Zulganef, 2008: 23). Tujuan penelitian ini adalah untuk menguji hipotesis dan menjelaskan hubungan variabel-variabel yang diteliti. Penelitian ini menggunakan pendekaan kuantitatif yang menekankan pada pengujian teori melalui pengukuran variabel penelitian dengan angka dan melakukan analisis data dengan prosedur statistik (Sugiyono, 2012: 50). Sedangkan karakteristik penelitian bersifat replikasi, sehingga hasil uji hipotesis harus didukung oleh penelitianpenelitian sebelumnya, yang diulang dengan kondisi lain yang kurang lebih sama.

\section{Population and Sampel}

Populasi dalam penelitian ini adalah perusahaan manufaktur yang terdaftar di Bursa Efek Indonesia periode 2013-2017 sebanyak 142 perusahaan. Perusahaan manufaktur dipilih karena praktik transfer pricing lebih sering terjadi pada sektor ini. Teknik penentuan sampel yang digunakan dalam penelitian ini adalah non probability sampling. Non probability sampling adalah teknik pengambilan sampel yang tidak memberi peluang atau kesempatan yang sama bagi setiap anggota populasi untuk dipilih menjadi sampel. Dalam penelitian ini, teknik non probability sampling yang digunakan adalah purposive sampling. Purposive sampling adalah penentuan sampel dengan pertimbangan tertentu (Sugiyono, 2013: 218). 
Tabel 1. Kriteria

\begin{tabular}{|c|c|c|}
\hline No & Kriteria & Total \\
\hline 1 & $\begin{array}{l}\text { Perusahaan manufaktur yang } \\
\text { terdaftar di Bursa Efek } \\
\text { Indonesia Periode 2013-2017 }\end{array}$ & 142 \\
\hline 2 & $\begin{array}{l}\text { Perusahaan manufaktur yang } \\
\text { tidak dikendalikan oleh } \\
\text { perusahaan asing }\end{array}$ & $(82)$ \\
\hline 3 & $\begin{array}{l}\text { Perusahaan manufaktur yang } \\
\text { mengalami kerugian }\end{array}$ & (33) \\
\hline 4 & $\begin{array}{l}\text { Perusahaan manufaktur yang } \\
\text { datanya tidak tersedia secara } \\
\text { lengkap dan melakukan } \\
\text { delisting }\end{array}$ & (4) \\
\hline \multicolumn{2}{|c|}{$\begin{array}{l}\text { Perusahaan yang memenuhi } \\
\text { kriteria }\end{array}$} & 23 \\
\hline
\end{tabular}

Variabel dependen pada penelitian ini adalah transfer pricing, yang diukur menggunakan metode dummy. Metode dummy adalah metode yang digunakan untuk menjadikan variabel kualitatif menjadi variabel kuantitatif (Ghozali, 2011: 160). Dengan menggunakan metode dummy, transfer pricing dikategorikan berdasarkan perusahaan yang melakukan dan tidak melakukan penjualan kepada pihak yang mempunyai hubungan istimewa. Perusahaan yang melakukan penjualan kepada pihak yang mempunyai hubungan istimewa diberi nilai 1 dan perusahaan yang tidak melakukan penjualan kepada pihak yang mempunyai hubungan istimewa diberi nilai 0 .

Variabel independen pertama dalam pernelitian ini adalah pajak. Pajak dalam penelitian ini diukur dengan menggunakan GAAP-ETR. GAAP-ETR adalah salah satu jenis effective tax rate yang dapat mengukur adanya tax avoidance. GAAP-ETR ini adalah effective tax rate berdasarkan pelaporan akuntansi keuangan yang berlaku. Pengukuran tax avoidance dengan menggunakan GAAPETR telah digunakan oleh sejumlah besar peneliti, yakni dengan cara membandingkan tax expense dengan pretax income (Mardiasmo 2003: 87).

Variabel independen ketiga adalah mekanisme bonus. Mekanisme bonus adalah imbalan yang diberikan pemilik perusahaan kepada manajer karena memenuhi sasaran kinerja perusahaan, seorang manajer mungkin memperoleh bonus berdasarkan laba bersih, atau menurut target kenaikan laba bersih (Hansen dan Mowen, 2005: 132). Mekanisme bonus dihitung dari index trend laba rugi (ITRENDLB) (Gusti Ayu, 2017: 1015).

\section{HASIL DAN PEMBAHASAN}

Uji Multikolinearitas

Uji multikolinearitas adalah keadaan dimana pada model regresi ditemukan adanya korelasi yang sempurna atau mendekati sempurna antar variabel independen. Pada model regresi yang baik seharusnya tidak terjadi korelasi yang sempurna atau mendekati sempurna di antara variabel bebas (korelasinya 1 atau mendekati 1). Untuk mengetahui suatu model regresi bebas dari multikolinearitas, yaitu dengan melihat angka VIF (Variance Inflation Factor) harus kurang dari 10 dan angka tolerance lebih dari 0,1 . Berdasarkan nilai VIF yang diperoleh seperti terlihat pada tabel di bawah ini, nilai tolerance untuk seluruh variabel bebas $>0,1$ dan nilai VIF seluruh variabel bebas $<10$. Dengan demikian dapat disimpulkan bahwa tidak terjadi multikolinearitas pada data tersebut.

Table 2. Uji Multikolinearitas

\begin{tabular}{|c|c|c|c|}
\hline \multicolumn{4}{|c|}{ Coefficients $^{a}$} \\
\hline \multirow{2}{*}{\multicolumn{2}{|c|}{ Model }} & \multicolumn{2}{|c|}{ Collinearity Statistics } \\
\hline & & Tolerance & VIF \\
\hline \multirow[t]{3}{*}{1} & Pajak &, 711 & 1,407 \\
\hline & Ukuran Perusahaan & 689 & 1,450 \\
\hline & Mekanisme Bonus & ,703 & 1,422 \\
\hline
\end{tabular}

a. Dependent Variable: Transfer Pricing 
Uji Kelayakan Model (Goodness of Fit Test)

Uji kelayakan model (goodness of fit test) diperlukan untuk memastikan tidak adanya kelemahan atas kesimpulan dari model regresi logistik yang diperoleh. Untuk memvalidasi kecocokan model atau goodness of fit test digunakan uji Hosmer and Lemeshow test dimana hipotesisnya adalah sebagai berikut:

Ho : Terdapat perbedaan antara model dengan data (model tidak fit).

Ha : Tidak Terdapat perbedaan antara model dengan data (model fit).

Model regresi logistik yang baik adalah model yang mampu memprediksi nilai yang diobservasinya atau model yang dapat diterima karena cocok dengan data observasinya (fit dengan data). Jika nilai Sig. yang diperoleh lebih kecil dari 0,05, maka hipotesis nol (Ho) ditolak. Dengan menggunakan program SPSS 21.0, diperoleh hasil uji Hosmer and Lemeshow dengan hasil sebagai berikut:

\section{Tabel 3}

\section{Hosmer and Lemeshow Test}

\begin{tabular}{|l|r|r|c|}
\hline Step & Chi-square & \multicolumn{1}{c|}{ df } & Sig. \\
\hline 1 & 14,330 & & 8 \\
\hline
\end{tabular}

Sumber: Output SPSS

Berdasarkan tabel output di atas, diketahui nilai Sig. yang diperoleh adalah sebesar 0,004 dan lebih kecil dari 0,05, sehingga sesuai dengan kriteria pengujian hipotesis adalah menerima $\mathrm{Ha}$ dan menolak Ho. Artinya tidak terdapat perbedaan antara model dengan data, sehingga model dapat dikatakan fit atau dengan kata lain model telah mampu memprediksi nilai observasinya dengan tepat.
Tabel 4. Summary of Parameter Model Estimation Result Y

\begin{tabular}{|c|c|c|c|c|c|c|c|}
\hline Model & $\mathrm{R}$ & $\begin{array}{c}\text { Nagelkerke's } \\
\text { (R Square) }\end{array}$ & $\begin{array}{c}\text { R2 } \\
\text { Change }\end{array}$ & B & SE & $\beta$ & $\mathrm{t}$ \\
\hline Model 1 & & .857 & & & & & \\
\hline Constan & & & & $-9,129$ & 1.855 & .000 & .000 \\
\hline Pajak & & & & 5.290** & 1.664 & $198.287^{* *}$ & .001 \\
\hline Bonus & & & & 8.235** & 1.815 & $3771.421^{* *}$ & .005 \\
\hline
\end{tabular}

Pada Tabel 4 dapat dilihat bahwa nilai Nagelkerke's R Square yang diperoleh adalah sebesar 0,857 atau $85,7 \%$. Hasil tersebut menunjukkan bahwa secara simultan pajak dan mekanisme bonus dalam memberikan kontribusi pengaruh sebesar $85,7 \%$ terhadap transfer pricing, sedangkan sebanyak $14,3 \%$ sisanya merupakan besar kontribusi pengaruh yang diberikan oleh faktor lain yang tidak diteliti.

Sedangkan Uji Wald (Wald statistic) digunakan untuk menguji hipotesis secara parsial. Apabila probabilitas (sig) lebih besar dari 0,05 maka variabel independen tidak memiliki pengaruh yang signifikan terhadap variabel dependen. Adapun jika probabilitas (sig.) lebih kecil dari 0,05, maka dapat dikatakan bahwa variabel independen memiliki pengaruh yang signifikan terhadap variabel dependen.

Berdasarkan tabel 3 nilai taksiran koefisien regresi logistik yang tersaji (variables in the equation) nilai Sig. variabel pajak adalah sebesar 0,001 lebih kecil dari 0,05 yang menunjukkan bahwa secara parsial pajak berpengaruh signifikan terhadap transfer pricing.

Variabel mekanisme bonus memiliki nilai Sig. yang diperoleh adalah sebesar 0,000 dan lebih kecil dari 0,05 yang menunjukkan bahwa 
secara parsial mekanisme bonus berpengaruh signifikan terhadap transfer pricing.

\section{KESIMPULAN DAN SARAN}

Hasil dari penelitian ini membuktikan bahwa motivasi pajak dapat mempengaruhi keputusan perusahaan untuk melakukan praktik transfer pricing. Hal ini didasarkan pada nilai hasil pengolahan statistik yang menunjukan probabilitas sebesar 0,001 yang lebih kecil dari tingkat signifikansi penelitian yakni 0,05. Praktik Transfer pricing diyakini dapat mengakibatkan berkurang potensi penerimaan pajak suatu negara dikarenakan perusahaan multinasional cenderung menggeser kewajiban perpajakannya dari negara-negara yang memiliki tarif pajak yang tinggi (high tax countries) ke negara-negara yang menerapkan tarif pajak rendah (low tax countries). Oleh karena itu, banyak perusahaan multinasional yang melakukan praktik transfer pricing sebagai alat untuk meminimalkan jumlah pajak yang harus dibayar. Sedangkan bagi perusahaan dengan melakukan praktik transfer pricing dipercaya mampu meningkatkan laba perusahaan karena dapat meminimalisir beban pajak menjadi lebih rendah. Temuan ini memperkuat penelitian yang dilakukan oleh (Clausing, 2003) yang menyatakan bahwa motivasi pajak mempengaruhi income shifting behavior di amerika serikat.

Hasil lainnya menunjukan bahwa mekanisme bonus dapat mempengaruhi perusahaan dalam melaksanakan kebijakan transfer pricing. Hal ini didasarkan pada nilai probabilitas sebesar 0,000 yang lebih kecil dari tingkat signifikansi 0,05 . Pemberian bonus kepada manajemen merupakan salah satu strategi untuk meningkatkan motivasi manajemen perusahaan atau direksi yang bertujuan untuk meningkatkan kinerja perusahaan. Disisi lain manajemen akan berupaya untuk dapat meningkatkan kinerja keuangan perusahaan, karena dengan peningkatan kinerja perusahaan tentu saja dapat mempengaruhi perolehan bonus yang akan di terima. salah satu cara yang dapat dilakukan oleh direksi untuk meningkatkan kinerja perushaan yaitu dengan cara menaikkan laba perusahaan pada setiap tahunnya. Maka cara yang paling mudah untuk diterapkan yaitu dengan melakukan manajemen laba atau bisa disebut dengan perekayasaan laporan keuangan. Transfer pricing dipercaya merupakan salah satu cara yang dapat dilakukan untuk meningkatkan laba yang diharapkan.

\section{DAFTAR PUSTAKA}

Brown. K. B. 2012. A Comparative Look at Regulation of Corporate Tax Avoidance. New York: Springer.

Ghozali, Imam. 2011. Aplikasi Analisis Multivariete dengan Program IBM SPSS 21. Semarang: Badan Penerbit Universitas Diponegoro.

Ghozali, Imam. 2016. Aplikasi Analisis Multivariete dengan Program SPSS. Semarang: Badan Penerbit Universitas Diponegoro.

Ikatan Akuntan Indonesia. 2013. Model Pelatihan Pajak Brevet C.Cetakan ke-6 Jakarta: Ikatan Akuntansi Indonesia.

Ikatan Akuntan Indonesia. 2014. Standar Akuntansi Keuangan. Jakarta: Ikatan Akuntansi Indonesia.. 
Hansen Don R, Maryanne M. Mowen. 2005. Akuntansi Manajemen. Jakarta: Erlangga.

Horngren, T, Charles, Srikant M, Datar, dan George Foster. 2008. Akuntansi Biaya: Dengan Penekanan Manajeria. Jakarta: Erlangga.

Jogiyanto, H.M. 2012. Metodologi Penelitian Bisnis. Edisi Kelima . Cetakan Pertama. BPFE-Yogyakarta. Yogyakarta

Mardiasmo. 2011. Perpajakan. Edisi Revisi 2011, Andi, Yogyakarta.

Nuryaman, dan Veronica Christina. 2015. Metodologi Penelitian Akuntansi dan Bisnis: Teori dan Praktik. Cetakan Pertama. Bogor: Ghalia Indonesia

Peraturan Direktur Jenderal Pajak Nomor PER-32/PJ/2011

Republik Indonesia. 2008. Undang-undang Nomor 36 Tahun 2008 Tentang Pajak Penghasilan. Jakarta

Sekaran, Uma. 2009. Research Methods For Business: Metodologi Penelitian Untuk Bisnis. Jakarta: Salemba Empat.

Simanjuntak, Timbul Hamonangan dan Mukhlis, Iman. 2012. Dimensi Ekonomi Perpajakan dalam
Pembangunan Ekonomi. Jakarta: Raih Asa Sukses

Suandy, Erly. 2011. Perencanaan Pajak. Edisi Kelima. Jakarta: Salemba Empat.

Sugiyono. 2003. Metode Penelitian Bisnis. Bandung.Pusat Bahasa Depdiknas.

Sugiyono. 2012. Metode Penelitian Kuantitatif Kualitatif dan $R \& D$. Bandung: Alfabeta.

Suliyanto, 2011. Ekonometrika Terapan: Teori dan Aplikasi dengan SPSS. Andi. Yogyakarta.

Sylvain R.F. Plasschaert. 1988. Pschedular, Global \& Dualistic Pattern of Income Taxation. Netherland : IBFD.

Undang-undang Republik Indonesia Nomor 36 Tahun 2008 tentang Perubahan atas Undang-undang Nomor 7 Tahun 1983 tentang Pajak Penghasilan.

Undang-Undang Republik Indonesia Nomor 16 Tahun 2009 Tentang Ketentuan Umum dan Tata Cara Perpajakan

Waluyo. 2013. Perpajakan Indonesia. Jakarta: Salemba Empat.

Zulganef. 2008. Metode Penelitian Sosial dan Bisnis. Edisi Pertama. Yogyakarta: Graha Ilmu. 
Vol. 7, No. 1, [Januari-Juni], 2019: 21-30

\section{Jurnal :}

Ayu, Gusti dan I Ketut Sujana. 2017.

Pengaruh Pajak, Mekanisme Bonus, dan Tunneling Incentive Pada Indikasi Melakukan Transfer Pricing. Jurnal Akuntansi Universitas Udayana

Clausing, K. A. (2003). T ax-motivated transfer pricing and US intrafirm trade, 87 , 2207-2223.

https://doi.org/10.1016/S0047-

2727(02)00015-4

Dyreng, et al. 2010. The Effect of Executives on Corporate Tax Avoidance.The Accounting Review, 85, 1163-

1189.

Hartati, W., et al,. 2014. Analisis Pengaruh Pajak dan Mekanisme Bonus Terhadap Keputusan Transfer pricing: Studi Empiris Pada Seluruh Perusahaan yang Listing Di Bursa Efek Indonesia. Simposium Nasional Akuntansi 2014.

Handayani, Desi dan Wulandari, Hesty. 2014. Pengaruh Kepemilikan Pemerintah dan Ukuran Perusahaan Terhadap Tarif Pajak Efektif Perusahaan. Jurnal Akuntansi Keuangan dan Bisnis. Vol. 7, Hal. 01-10.

Hashemi Rodhian, Zulaikha. 2013. Pengaruh Krakteristik Corporate Governance
Terhadap Effective Tax Rate. Jurnal Universitas Diponegoro

Julaikah, Nurul, 2014, "Hampir Semua Perusahaan Asing Akali Bayar Pajak", Merdeka, diakses dari http://m.merdeka.com pada tanggal 15 April 2014

Kiswanto, N., dan Anna Purwaningsih, 2014. Pengaruh Pajak, Kepemilikan Asing, dan Ukuran Perusahaan Terhadap Transfer Pricing Pada Perusahaan Manufaktur di BEI Tahun 2010-2013. Jurnal Universitas Atma Jaya.

Machfoedz. 1994. Pengaruh Rasio Keungam Terhadap Perubahan Laba. Jurnal Riset Akuntansi Indonesia.

Purwanti, Lilik. 2010. Kecakapan Managerial, Skema Bonus, Managemen Laba, dan Kinerja Perusahaan. Jurnal Aplikasi Manajemen Vol. 8. No. 2.

Rusydi. 2013. Pengaruh Ukuran Perusahaan Terhadap Aggressive Tax Avoidance $D i$ Indonesia. Jurnal Akuntansi Multiparadigma Vol. 4 No. 2.

Sari, Diana. 2004. Transfer Pricing dan Aspek Perpajakannya. Jurnal Bisnis, Manajemen dan Ekonomi Vol.6 No.2 Universitas Widyatama. 
Suryatiningsih, N. dan Siregar, S. V. 2009.

Pengaruh Skema Bonus Direksi

Terhadap Aktivitas Manajemen Laba:

Studi Empiris Pada BUMN Periode

Tahun 2003-2006. Jurnal Simposium

Nasional Akuntansi, Pontianak. 23-26

Juli: 1-30.

Yuniasih, Wayan, et al,. 2012. Pengaruh Pajak

Dan Tunneling Incentive Pada

Keputusan Transfer Pricing

Perusahaan Manufaktur Yang Listing

Di Bursa Efek Indonesia. Jurnal

Universitas Udayana. 